\title{
Early Implant Placement with Delayed Loading in Anterior Aesthetic Zone - A Case Report
}

\author{
Dr. Manoj Humagain, ${ }^{1}$ Dr. Simant Lamichhane, ${ }^{1}$ Dr. Mahima Subba, ${ }^{1}$ \\ Dr. Manisha Neupane, ${ }^{1}$ Dr. Asmita Dawadi ${ }^{1}$ \\ ${ }^{1}$ Department of Periodontology, Kathmandu University School of Medical Sciences, \\ Dhulikhel, Kavrepalanchok, Nepal.
}

\begin{abstract}
To prevent the sequelae of hard and soft tissue loss after tooth extraction, future need of bone augmentation procedures and utilisation of benefits during early stages of tissue healing, early implant promises to be an armoury for dental implantologists to perfectly simulate the natural dentition in anterior aesthetic areas. Here, a case of 30 years old male with a missing \#11 (according to two-digit numbering system) planned for early implant placement and immediate temporisation with delayed loading is presented.

Keywords: Aesthetics; delayed dental implant loading; dental implants; immediate implant loading.
\end{abstract}

\section{INTRODUCTION}

The expected outcomes of teeth replacement in anterior aesthetic zones are inconsistent in terms of aesthetics and function. The common options for single-tooth replacement are: removable partial denture, fixed partial denture, and implants. ${ }^{1,2}$ Predictable long-term results favour use of dental implants over other treatment options. ${ }^{3}$ Implant placement during early stages of tissue healing prevents vertical collapse around implant sites, adds keratinised tissue all around, and allows easier apical engagement. ${ }^{4}$

This case report highlights the importance of proper handling of tissues during early implant placement and immediate temporisation to prevent hard and soft tissue loss and ensure adequate aesthetics and function.

\section{CASE REPORT}

A 30-year-old male patient reported to the Department of Periodontology, Kathmandu University School of Medical Sciences, Dhulikhel with a chief complaint of missing tooth in upper front region which was lost because of trauma

\section{Correspondence:}

Prof. Dr. Manoj Humagain

Department of Periodontology, Kathmandu University School of Medical Sciences, Dhulikhel, Kavrepalanchok, Nepal.

email:mhumagain@gmail.com

\section{Citation}

Humagain M, Lamichhane S, Subba M, Neupane M, Dawadi A. Early Implant Placement with Delayed Loading in Anterior Aesthetic Zone - A Case Report. J Nepal Soc Perio Oral Implantol. 2020 Jul-Dec;4(8):89-92 one month back. Extraction was done at a private clinic and was uneventful (Figure 1). Medical history revealed no obvious findings. On intraoral examination, oral hygiene was fair, missing \#11 (according to two-digit numbering system), medium lip line with good amount of keratinised tissue around the missing tooth was noted. Patient was given various treatment options available for replacement of missing tooth. He opted for implant therapy, informed consent was taken and was referred for radiographic evaluation using cone beam computed tomography (CBCT). CBCT report showed there was adequate mesiodistal width and adequate distance form vital structure. However, the report showed that slight crestal modification was required due to inadequate labiopalatal width at the crest level (Table 1, Figure 2, 3). After considering the СВСТ finding and cast analysis, $3.1 \times 11 \mathrm{~mm}$ NR Line implant (Dentium Co.) was planned for the patient.

Following complete aseptic techniques, the surgical area was anaesthetised by use of local infiltration technique with

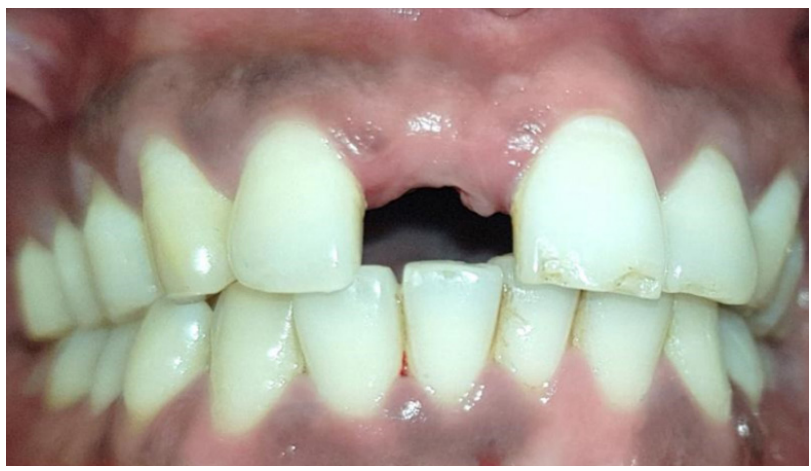

Figure 1: Intraoral preoperative view. 
Table 1: Cone beam computed tomography report.

\begin{tabular}{|c|c|c|c|c|c|}
\hline Edentulous tooth region & \multicolumn{5}{|c|}{ Available mesidistal width at the crestal level from midline } \\
\hline 11 region & \multicolumn{5}{|c|}{$8.25 \mathrm{~mm}$} \\
\hline \multicolumn{6}{|c|}{ Available buccopalatal dimension and distance to the floor of canal cavity from the crest. } \\
\hline \multirow[t]{2}{*}{11 region slice no. 5.25} & $\begin{array}{l}\text { Crestal bone need } \\
\text { to modify }(\mathrm{mm})\end{array}$ & $\begin{array}{l}\text { Crestal width } \\
(\mathrm{mm})\end{array}$ & $\begin{array}{l}\text { Mid width } \\
(\mathrm{mm})\end{array}$ & $\begin{array}{l}\text { Distance from the crest to } \\
\text { floor of canal cavity (mm) }\end{array}$ & $\begin{array}{c}\text { Overall bone } \\
\text { density }\end{array}$ \\
\hline & 0.95 & 4.41 & 7.81 & 17.73 & D3 \\
\hline
\end{tabular}

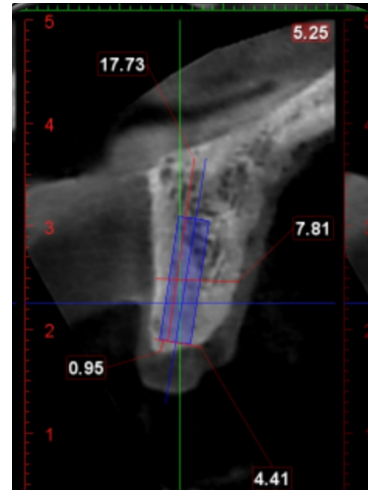

Figure 2: Cone beam computed tomography analysis.

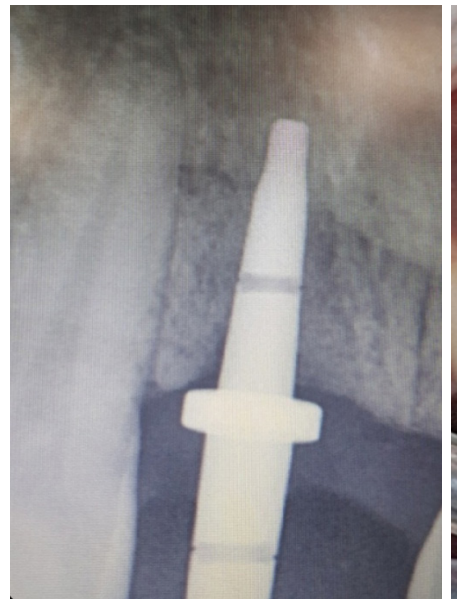

Figure 5: Intraoral periapical X-ray of guide pin.

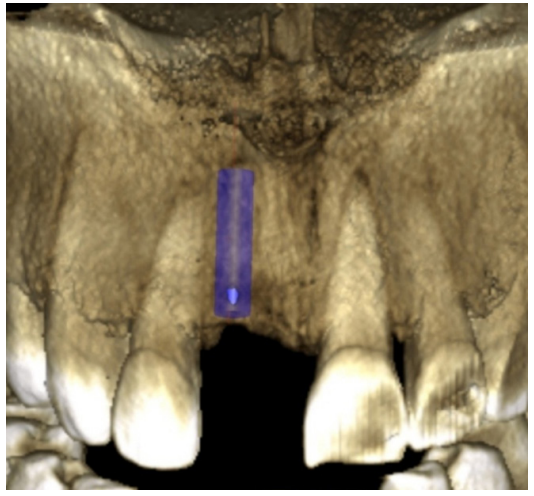

Figure 3: Three-dimensional cone beam computed tomography analysis.

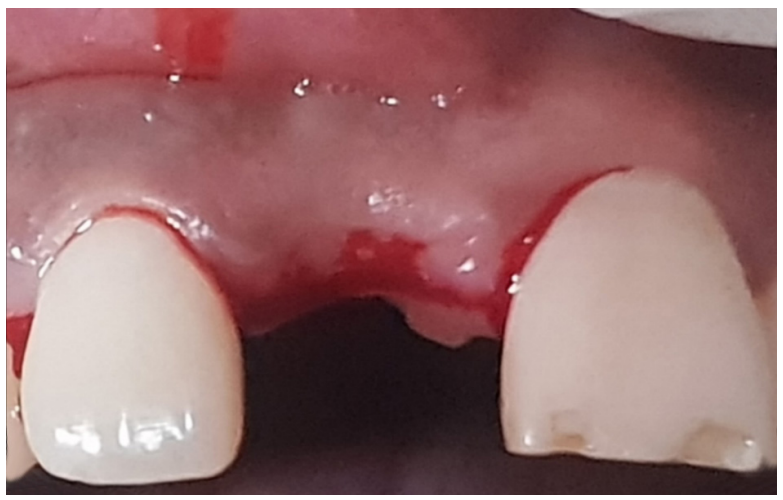

Figure 4: Midcrestal incision.

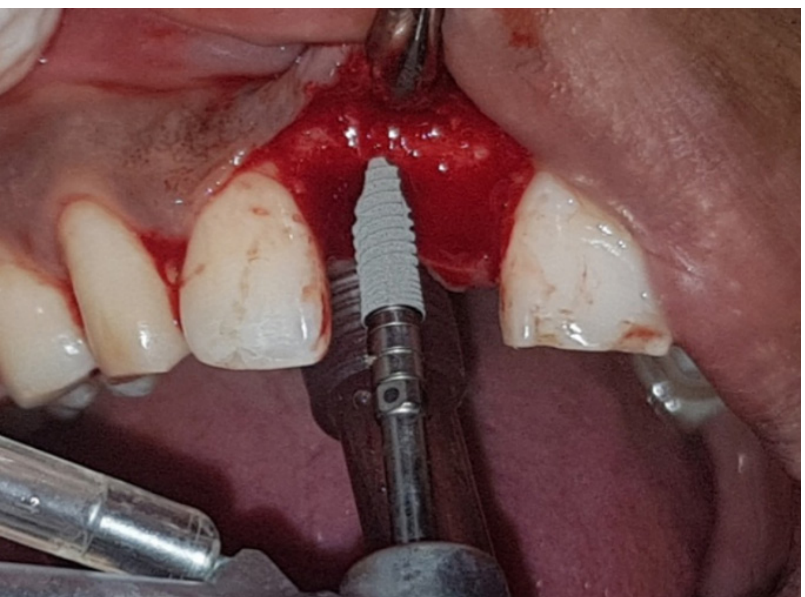

Figure 6: Implant insertion $3.1 \times 11 \mathrm{~mm}$.

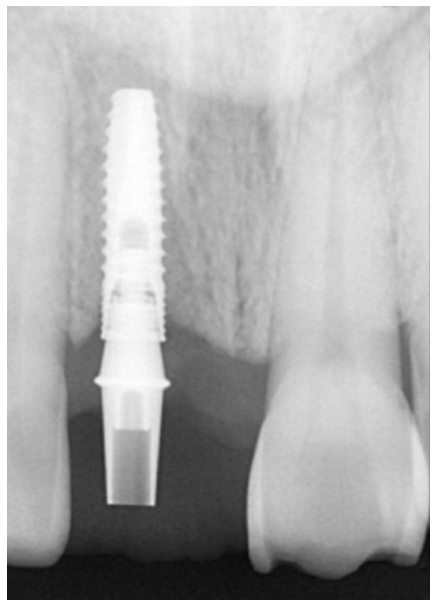

Figure 7: Intraoral periapical X-ray of implant.
2\% Lignocaine $\mathrm{HCl}$ with 1:2,00,0000 epinephrine. Midcrestal incision was given using \#15 BP blade and a full thickness envelope flap was elevated gently to visualise the crest of alveolar bone (Figure 4).

Soft tissue remnants around the implant surgical bed were removed and irrigated using normal saline. Surgical bed preparation was started using initial pilot drill of $2.6 \mathrm{~mm}$ from implant surgical kit (Dentium Co. Korea). Guide pin was then inserted into the osteotomy site for checking parallelism. Intraoral periapical radiograph was taken for checking the proximity of incisive canal and parallelism with adjacent tooth (Figure 5).

Subsequent sequential drilling was done till the desirable length and the diameter of the osteotomy is achieved. Intraoral periapical radiograph was taken again for confirming the final implant placement (Figure 6 and 7).

Prosthetic abutment of gingival height $2 \mathrm{~mm}$ was fixed to the implant fixture and immediate chair side temporisation was done using composite resin and kept out of contact from lower incisors. Two interrupted silk sutures were placed (Figure 8, 9).

The patient was well informed about possible complications after implant surgery. Chlorhexidine mouthwash $0.2 \% 10 \mathrm{ml}$ twice daily for 10 days along with analgesics as per needed was prescribed. Patient follow-up visit was scheduled after one week of surgery for suture removal and re-evaluation. On re-evaluation soft tissue healing was satisfactory and patient was recalled after four months for final prosthesis. Patient missed his follow-up and presented after six months. Oral prophylaxis was done and temporary prosthesis was 


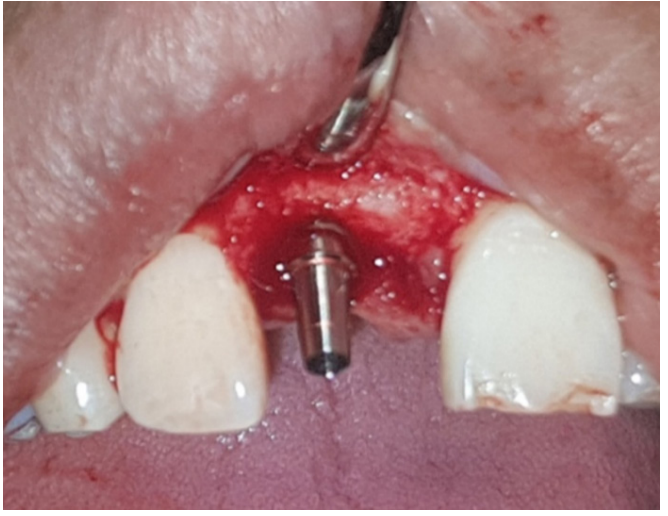

Figure 8: Abutment for temporisation.

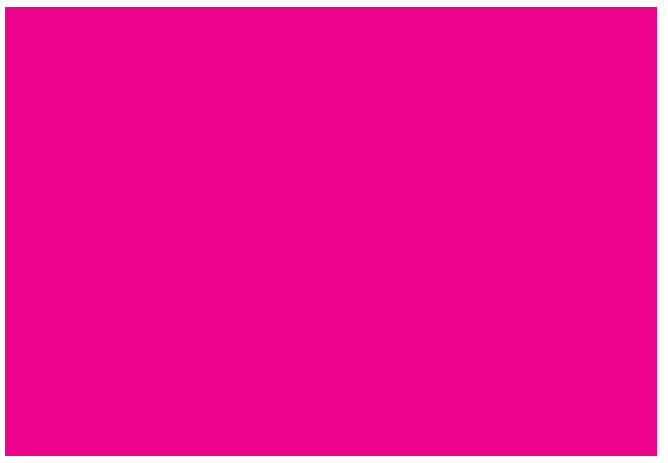

Figure 10:

removed, impression post was connected to implant fixture and closed tray impression was made. Metal ceramic crown was fabricated in lab and was cemented using luting cement with good satisfactory results (Figure 10, 11).

Traditionally, implant therapy was predominantly performed in healed sites of fully edentulous patients. ${ }^{4}$ Treatment concept was totally based on osseointegration and primary objective of implant therapy was aimed at improving masticatory function and the quality of life. ${ }^{5}$ However, this conventional therapy was not so attractive for both the clinician as well as for the patient because of lengthier treatment time. In addition, the post-extraction consequences of alveolar bone remodelling posed a great challenge in attaining good aesthetic results. ${ }^{4}$ To overcome the demerits of conventional implant, Wilfried Schulte in 1978 developed an immediate implant system called as Tubinger implant which was a ceramic implant (Al2O3). ${ }^{6}$ Tubinger implant system was very popular during 1980s but due to implant fracture as ceramic materials were brittle it lost its popularity completely. Later a few case reports were published between 1990-2003 which was considered as trial and error phase of immediate implant placement. ${ }^{4}$ Thus, a complete guideline for timing of implant placement was designed by

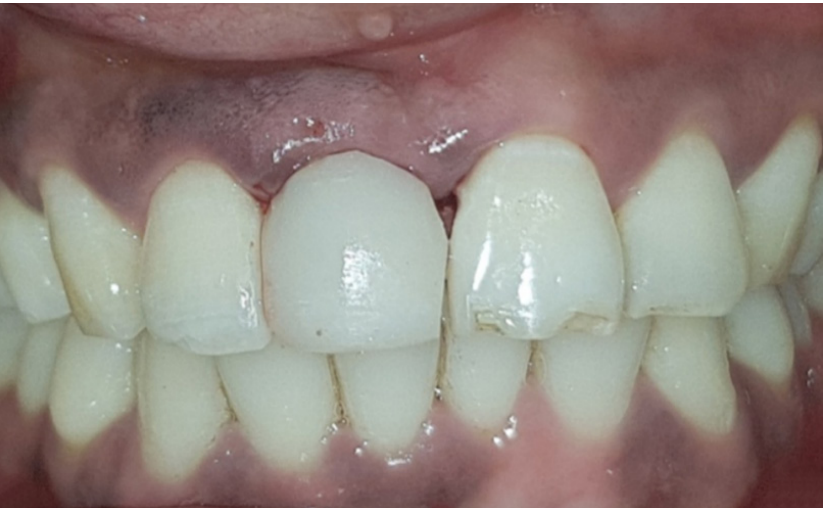

Figure 9: Implant supported provisional restoration with respect to \# 11.

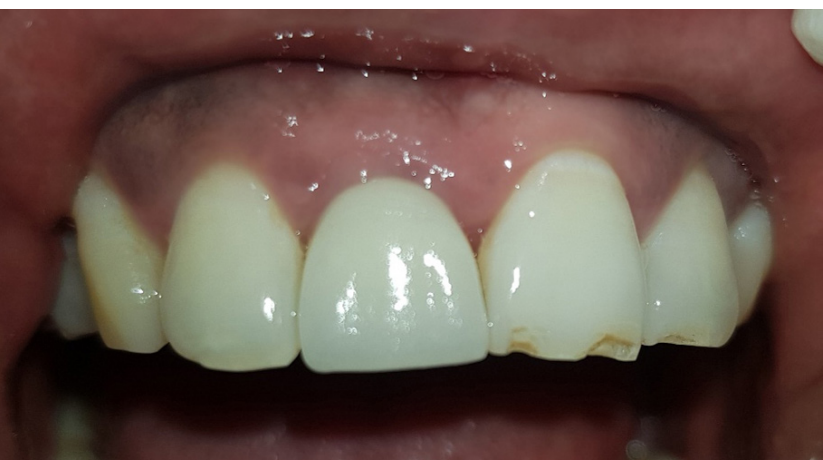

Figure 11: Final implant supported metal ceramic crown.

International Team for Implantology in 2003 and 2008 which included immediate implant (implant placed on same day of extraction), early implant with soft tissue healing (between 4-8 weeks post-extraction), early implant with partial bone healing (between 12-16 weeks post-extraction) and delayed implant (>6 months post-extraction). ${ }^{4}$ Immediate implants was found to be associated with midfacial recession of about $26 \%$ when compared with early implant placement. ${ }^{7}$ But with early implant placement, Chappuis et al. in 2015 found up to seven folds increase in soft tissue in case of thin or damaged facial wall which ensures thick mucoperiosteal flap with good vascularity for healing, less chance of flap tear and need of soft tissue grafts augmentation.8 Other advantages of early implant with soft tissue healing includes additional 2-3 mm of keratinised mucosa around implant due to spontaneous soft tissue healing and apical bone formation. ${ }^{4}$ The presented case resulted in excellent functional and aesthetic outcome with the appreciable features associated with early implant with soft tissue healing like absence of any soft tissue recession, no vertical height loss after six months of implant follow-up, and adequate amount of soft tissue barrier around the implant in all directions. 


\section{REFERENCES}

1. Belser U, Martin W, Jung R, Hammerle CH, Schmik B, Morton D, Buser D. ITI Treatment Guide, Volume 1: Implant Therapy in the Esthetic Zone. Single-tooth Replacements. Berlin: Quintessence. 2007.

2. Misch CE. Rationale for dental implants In: Misch CE. Contemporary Implant Dentistry. 3rd ed, St. Louis, MO: Saunders Elsevier; 2008.p1-25.

3. Jung RE, Al-Nawas B, Araujo M, Avila-Ortiz G, Barter S, Brodala N, et al. Group 1 ITI Consensus Report: The influence of implant length and design and medications on clinical and patient-reported outcomes. Clin Oral Implants Res. 2018;29 Suppl 16:69-77.

4. Bser D, Chappuis V, Belser UC, Chen S. Implant placement post extraction in esthetic single tooth sites: when immediate, when early, when late? Periodontol 2000. 2017;73(1):84-102.

5. Branemark PI, Adell R, Breine U, Hansson BO, Lindstrom J, Ohlsson A. Intraosseous anchorage of dental prostheses. I. Experimental studies. Scand J Plast Reconstr Surg. 1969; 3:81-100.

6. Schulte W, Kleineikenscheidt H, Linder K, Schareyka R. The Tübingen immediate implant in clinical studies. Dtsch Zahnarztl Z. 1978;33(5):348-59.

7. Chen ST, Buser D. Esthetic outcomes following immediate and early implant placement in the anterior maxilla - a systematic review. Int J Oral Maxillofac Implants 2014: 29 Suppl:186-215.

8. Chappuis V, Engel O, Shahim K, Reyes M, Katsaros C, Buser D. Soft tissue alterations in esthetic postextraction sites: a 3-dimensional analysis. J Dent Res. 2015;94(9 Suppl):187S-93S. 